\title{
Compensatory growth response of freshwater prawn (Macrobrachium rosenbergii) polycultured with Indian major carp, Catla (Catla catla)
}

\begin{abstract}
With a view to evaluate the compensatory growth response, production and survival of prawn (Macrobrachium rosenbergii) and catla (Catla catla) under polyculture system, an experiment was conducted at the Faculty of Fisheries Field Laboratory in Bangladesh Agricultural University campus from 20 March 2006 to 20 June 2006. The experiment was consisted of three treatments with three replications for each. The three treatments were: fed to satiation twice a day $\left(T_{1}\right)$, fed every alternate day $\left(T_{2}\right)$ and fed every two days of interval $\left(\mathrm{T}_{3}\right)$. SABINCO prawn feed was used as supplementary diet for the experiment. The stocking densities for prawn and catla were $40 / \mathrm{dec}$. and $12 / \mathrm{dec}$., respectively. The initial weights at stocking were: $50 \mathrm{~g}$ for catla in all the treatments, and 5.8, 6.4 and $6.2 \mathrm{~g}$ for prawn in $\mathrm{T}_{1}, \mathrm{~T}_{2}$ and $\mathrm{T}_{3}$ respectively. The water quality parameters were almost similar in all treatments and also were within an acceptable range of fish culture. The survival rate for catla was $100.0 \%$ in $\mathrm{T}_{1}, 91.6 \%$ in $\mathrm{T}_{2}$ and $83.3 \%$ in $\mathrm{T}_{3}$, while for prawn was $85.0 \%$ in $\mathrm{T}_{1}$, $71.0 \%$ in $\mathrm{T}_{2}$ and $69.0 \%$ in $\mathrm{T}_{3}$, respectively. The average weight of prawn was much lower in $\mathrm{T}_{3}$ and $\mathrm{T}_{2}$ than those in $\mathrm{T}_{1}$. The best FCR value was found in $\mathrm{T}_{2}(1.80)$ followed by $\mathrm{T}_{3}(1.85)$ and $T_{1}(1.98)$ in this order. The average highest gross yield was obtained from $T_{1}(1656 \mathrm{~kg} /$ ha) followed by $T_{2}(1077 \mathrm{~kg} / \mathrm{ha})$ and $\mathrm{T}_{3}(1127 \mathrm{~kg} / \mathrm{ha})$, while the production of prawn was $\mathrm{T}_{1}(791 \mathrm{~kg} / \mathrm{ha}), \mathrm{T}_{2}(517 \mathrm{~kg} / \mathrm{ha})$ and $\mathrm{T}_{3}(429 \mathrm{~kg} / \mathrm{ha})$, respectively. However, no significant differences were found in the total yield in $\mathrm{T}_{2}$ and $\mathrm{T}_{3}$. The total costs of production for the three treatments were: $\mathrm{T}_{1}(125.93 \mathrm{Tk} / \mathrm{kg}), \mathrm{T}_{2}(143.21 \mathrm{Tk} / \mathrm{kg})$ and $\mathrm{T}_{3}(146.71 \mathrm{Tk} / \mathrm{kg})$, while the profits were: $\mathrm{T}_{1}(104.07 \mathrm{Tk} / \mathrm{kg}), \mathrm{T}_{2}(55.86 \mathrm{Tk} / \mathrm{kg})$ and $\mathrm{T}_{3}(24.60 \mathrm{Tk} / \mathrm{kg})$ in which the benefit cost ratio were found to be 1:0.83, 1:0.39 and 1:0.17, respectively. The results indicate that every day feeding had provided good growth and economic returns and thus seemed to be most practicable and viable feeding options for prawn-fish polyculture. Therefore, prawnfish polyculture with regular feeding provides satisfactory growth and production.
\end{abstract}

Keywords: polyculture, feed, growth response, fish, Macrobrachium rosenbergii
Volume 4 Issue 5 - 2019

\author{
Mt Shamima Yasmin,' M Zahangir Alom,' M \\ Aminur Rahman² \\ 'Department of Fisheries, Matshya Bhaban, Dhaka-1000, \\ Bangladesh \\ ${ }^{2}$ Department of Fisheries and Marine Bioscience, Jashore \\ University of Science and Technology, Jashore-7408, Bangladesh
}

\author{
Correspondence: Dr. Md.Aminur Rahman, Professor, \\ Department of Fisheries and Marine Bioscience, Jashore \\ University of Science and Technology, Jashore-7408, Bangladesh, \\ Tel +88 042I-6I097 (Ext. 353), +88 0I734-142726, \\ Email aminur1963@gmail.com, amin2019@just.edu.bd
}

Received:September 22, 2019 | Published: October 25, 2019
Abbreviations: PL, post larvae; BAU, Bangladesh agricultural university; FCR, feed conversion ratio; ANOVA, analysis of variance; DO, dissolved oxygen; SGR, specific growth rate

\section{Introduction}

Fish is an essential daily food item for the people of Bangladesh and as such demand for fish is increasing with the increase of human population. In the early sixties, per capita annual fish consumption was $12 \mathrm{~kg}$ per person, which presently comes down to $9.0 \mathrm{~kg}$ in spite of the significant growth in fish production. Now, fish has not remained as bountiful as in the past due to man-made and natural ecological alterations, over fishing and resource use conflicts occurring over the last two or three decades. This has disturbed the nation and many have been realizing the fact that alike any other natural resource, fish also need scientific management, if it is to be sustained. However, the elements of fish culture have been introduced more recently and the country is in the process of slowly changing the source of fish production from hunting to an aquaculture pursuit. Though the production has increased, the present per capita fish intake ( $28 \mathrm{~g} /$ day) is still below the recommended amount ( $49 \mathrm{~g} /$ day) and the annual growth rate is gradually decreasing. ${ }^{1}$ On the other hand, due to population growth, the demand for fish has been increasing tremendously, which is very difficult to overcome without having concerted efforts on getting increased production. As augmentation of fish production from rivers and estuaries is quite difficult, we need to depend on pond aquaculture for increased production and supply of fish, employment generation and poverty alleviation in the rural areas of Bangladesh. ${ }^{2}$ Moreover, the farmers can manage and utilize the small water bodies properly and can minimize the production cost by adopting aquaculture system. Aquaculture sector is expected to contribute to the reduction in gap between demand and supply of fishery products in the country. In addition to domestic demand, export market is equally important for the country to ease the balance of payment.

Aquaculture is an age old practice in Bangladesh. Based on the habitat, there are two types of aquaculture in Bangladesh viz., freshwater and coastal aquaculture. Freshwater aquaculture is comprised mainly of pond aquaculture, especially polyculture of carps having native and exotic origin. Coastal aquaculture is comprised primarily of shrimp farming. Presently, high valued shrimp from coastal aquaculture is the main export earning commodity. Aquaculture system has now stepped towards semi-intensive type. Small scale resource-poor farmers have adapted to the improved traditional and semi-intensive farming system.

The major indigenous species for aquaculture in Bangladesh are comprised of catla (Catla catla), rohu (Labeo rohita), mrigal (Cirrhinus 
mrigala) and calibaush (Labeo calbasu), while the exotic species in aquaculture are silver carp (Hypophthalmichthys molitrix), grass carp (Ctenopharyngodon idella), common carp (Cyprinus carpio), Thai pangas (Pangasius hypophthalmus), tilapia (Oreochromis niloticus), sharpunti (Barbonymus gonionotus) etc.

Polyculture, the simultaneous culture of several species of fish with different feeding habits, is an efficient means of increasing fish production. The success of this system lies in the choice of right combination of fish species. ${ }^{3}$ The basic principle of polyculture is applied for the best utilization of natural foods of different strata and zones without any harm to each other. It is a fact that polyculture may produce an expected result if ponds are stocked with species having different feeding habits in proper ratios based on the assumption that fish growth is an expression of their reaction to among other things, the sources of natural food in the environment. ${ }^{4}$ Polyculture can improve pond environmental conditions, first of all feeding conditions for fish, oxygen budget of ponds and control of aquatic weeds. ${ }^{5}$ The key technique of polyculture is based on the relationship between participatory organisms at different levels of food chain of the environment. Selection of fish species plays an important role for any culture practice. Stocking density of different fish species in a polyculture system also plays a vital role on overall production.

The economy of Bangladesh is largely dependent on aquaculture. From this point of view, fish and fisheries are inseparable from the culture and heritage of Bangladesh. They play a significant role in the country's socio-culture and economic life, providing food, employment and foreign exchange. ${ }^{6}$ Fish is the main source of animal protein to the people of Bangladesh where about $63 \%$ of the animal protein supply is provided by the fish. ${ }^{7}$ Annual fish production in 2003-2004 was 2.10 million mt, which were 1.26 million MT in 1995 96 and 0.95 million in 1991-92..$^{7}$ About $63,377 \mathrm{mt}$ fish and fisheries products are exported to foreign countries and earned about Tk. 25,371 million in 2004-05 fiscal year. The contribution of fish and fisheries products in foreign exchange craning is $5.76 \%$ and contribution to GDP was $4.92 \%$ in $2003-04 .^{1}$

In 1988-89 fiscal year, Bangladesh earned Tk. 3,820.5 million by exporting frozen shrimp and prawn and this volume rose up to Tk.14, 478.0 million in 2001-2002 fiscal year. At the same fiscal year frozen shrimp and prawn alone contributed about $92.73 \%$ of the total export values through the export of various fisheries commodities. ${ }^{7}$ Around 1.2 million people ( $10 \%$ of the total population) are directly involved with fisheries activities and about 3.08 million are involved indirectly. About $13 \%$ of the rural households are involved in this sector and it provides employment opportunity to about $7 \%$ of the total population.

Now the slogan "quality seed and quality feed" is the prerequisite for better production in aquaculture operation. So, the importance of feed in aquaculture has increased with the intensification of fish culture and now fish production fully depends on quality feed. Feed cost is the highest single operational cost in all kinds of aquaculture. On the other hand, use of complete artificial diet is not possible in part of most of the farmers in Bangladesh due to lack of necessary financial support. Moreover, around $50 \%$ of the supplied feed is practically misused due to inappropriate feeding management and improper species combination in polyculture systems as reported by many authors. So, the farmers failed to get expected yield through utilizing the full growth potential of fish and productivity of the pond as well. Considering these important technical issues as influential factors in aquaculture production, this problem was undertaken in the present study to explore the possibilities of effective use of supplied feed and with a view to reduce the fish production cost of the poor farmers of Bangladesh.

The major objectives of the present study were to know the influence of feeding and feed rationing on the growth and production of fish and prawn under polyculture system and to develop a suitable technique to increase the production by minimizing the feed cost.

\section{Materials and methods}

\section{Location of the experiment}

The present research was carried out at the faculty of Fisheries field laboratory in Bangladesh Agricultural University, Mymensingh (Figure 1) during the month of March 2006 to June 2006.

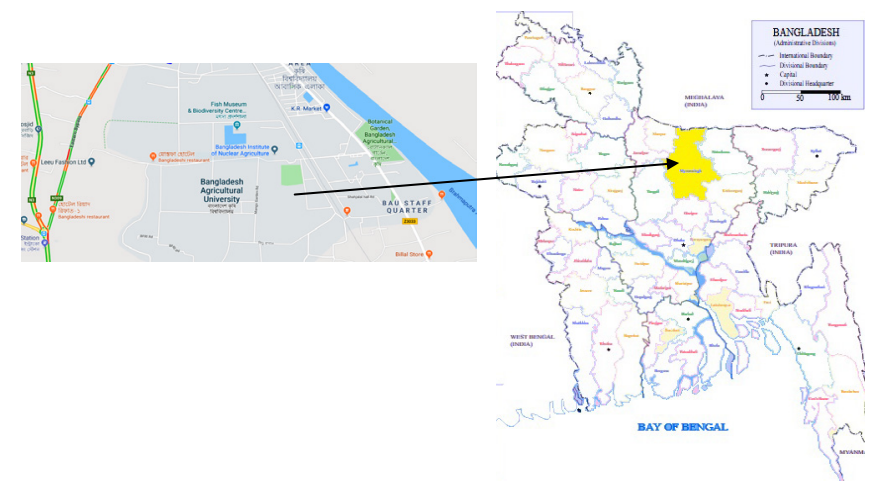

Figure I Map showing the location of the experimental site.

\section{Experimental ponds}

The experiment was conducted in 9 earthen ponds with 1.5 meter of water depth. The size of each experimental pond was 1.0 decimal.

\section{Catchment basin}

The catchment area of the study was at the Bangladesh Agriculture University, Mymensingh, located at the North-West part of Bangladesh $\left(24.71^{\circ} \mathrm{E}\right.$ and $\left.90.42^{\circ} \mathrm{N}\right)$. It is typically the tropical zone of the county. Average lowest temperature $\left(11^{\circ} \mathrm{C}\right)$ was recorded in the month of January, while the highest temperature $\left(33.4^{\circ} \mathrm{C}\right)$ was in April. The Soil quality of the catchment area was clay and clay-loamy. There was a very little scope of contamination in the experimental area. Only the inorganic fertilizer and bottom soil was the source of potential contaminants in the experimental ponds.

\section{Experimental design}

The experiment was commenced with the establishment of groups of fish according to the following feeding regime. Each treatment had three replications.

Feeding trials of different treatments were as follows:

a. Treatment 1: No deprivation, hand feeding to satiation twice per day.

b. Treatment 2: 1 day deprivation, followed by 1 day feeding $(1: 1)$.

c. Treatment 3: 2 days deprivation, followed by 2 days feeding (2:2).

\section{Pond preparation}

Aquatic weeds, and other undesirable fish and organisms were removed from the ponds manually. All the ponds were prepared 
and embankments were repaired by excavating the bottom and were kept exposed to sunlight, and lime was then applied to the ponds at the rate of $1 \mathrm{~kg} / \mathrm{dec}$. After 3 days of liming, ponds were filled with underground water through a flexible plastic pipe from a deep tubewell. Then the ponds were fertilized with inorganic (Urea and TSP @ $200 \mathrm{~g} / \mathrm{dec}$ and $100 \mathrm{~g} / \mathrm{dec}$, respectively) and organic fertilizer (Cow dung@ $2.5 \mathrm{~kg} / \mathrm{dec}$ ), and left for 7 days to allow the development of natural foods in the healthy pond ecosystem.

\section{Fingerling and post larvae (PL) collection and stocking}

Netting was done in the experimental ponds to remove aquatic insects 3 days before stocking. Fingerlings were collected from Jhalak hatchery, Gouripur, Mymensingh. In this experiment, good quality fingerlings and juveniles were selected, and then transported in the oxygenated polythene bags to the field laboratory of the Faculty of Fisheries, Bangladesh Agricultural University (BAU), Mymesingh. Before releasing the fingerlings and juveniles into the experimental ponds, the initial length and weight of fishes and prawns were recorded in ' $\mathrm{cm}$ ' and ' $\mathrm{g}$ ' with the help of a measuring scale and a sensitive portable battery operated balance (Model HL 400EX), respectively. Prior to releasing the fish fingerlings in the ponds, they were acclimatized with the pond water for half an hour.

\section{Feeding}

Pelleted feed (SABINCO fish feed limited, Trisal, Mymensingh) at the rate of $5 \%$ body weight of prawn was applied for during the experiment. On each feeding day, the prawns were fed at 9.0 am and $5.0 \mathrm{pm}$. The proximate composition of the used feed is shown in Table 1.

Table I Proximate composition of feed used in the experiment

\begin{tabular}{ll}
\hline Components & Percentage (\%) \\
\hline Moisture & 11 \\
Protein & 25 \\
Lipid & 4 \\
Ash & 17 \\
\hline
\end{tabular}

\section{Fertilization}

The experimental ponds were inspected twice daily between $8.00 \mathrm{am}$ to $9.00 \mathrm{am}$ and between $4.00 \mathrm{pm}$ to $5.00 \mathrm{pm}$ to observe any abrupt change in water condition or behavior of fish and prawn. All the treatments were subjected to the same regime of feeding and fertilization. All ponds were fertilized with Urea and T.S.P. at the rate of $100 \mathrm{~g} / \mathrm{dec}$. at weekly intervals. After stocking of fish and prawn, liming was done at the rate of $0.5 \mathrm{~kg} / \mathrm{dec}$. in all the ponds at fifteen days of interval.

\section{Sampling of fish and prawn}

The fishes and prawns were sampled fortnightly by using a cast net and in each sampling, ten fishes and prawns were weighed separately to assess the health condition of fish and their growth, using a portable electrical balance (Model OHAUS).

Study on water quality parameters: Water quality parameters (temperature, dissolved oxygen, $\mathrm{pH}$ etc.) of the experimental ponds were monitored and recorded at every ten days interval throughout the culture period. All the parameters were measured using surface water at the pond site.

\section{Methods used for water quality analysis}

\section{1) Water temperature $\left({ }^{\circ} \mathrm{C}\right)$}

Temperature of pond water $\left({ }^{\circ} \mathrm{C}\right)$ was recorded with the help of a thermometer (YSL Model 58, USA) between $9.00 \mathrm{am}$ and $10.00 \mathrm{am}$.

\section{2) Dissolved oxygen (ppm)}

Dissolved oxygen was measured directly using a portable water proof digital oxygen meter (HANNA Instrument Model: HI-9142, Portugal), from $9.00 \mathrm{am}$ to $10.00 \mathrm{am}$.

\section{3) Transparency (cm)}

Transparency was measured with a secchi disc of $20 \mathrm{~cm}$ diameter between 9.00 am and $10.00 \mathrm{am}$.

\section{4) Hydrogen ion concentration $(\mathrm{pH})$}

$\mathrm{pH}$ was determined with the help of a portable $\mathrm{pH}$ meter (HANNA Instruments, Model:HI-9142, Portugal) between 9.00 am and 10.00 am.

\section{Harvesting of fish and prawn}

After 90 days of rearing, the fishes and prawns were harvested on June 20, 2006. Primarily harvesting was done by repeated netting using a berjal. Final harvesting was done by dewatering the ponds with low lift Pedrollo pump (2 HP). During harvesting all the fishes and prawn were counted and weighed individually for each pond to assess the survival rate and production.

\section{Analysis of experimental data}

Experimental data collected during the whole experimental period were analyzed as follows:

\section{a. Weight gain (g)}

Weight gain $=$ Mean final fish weight - Mean initial fish weight

b. Percent weight gain $(\%)$

Percent weight gain $=\frac{\text { Mean final fish weight }- \text { Mean initial fish weight }}{\text { Mean initial fish weight }} \times 100$

\section{c. Average daily gain (ADG)}

$$
\mathrm{ADG}=\frac{\text { Mean final fish weight }- \text { Mean initial fish weight }}{\mathrm{T}_{2}-\mathrm{T}_{1}}
$$

d. Specific growth rate (SGR) (\% per day)

$\operatorname{SGR}(\%$ day $)=\frac{\operatorname{LogeW}_{2}-\text { LogeW }_{1}}{\mathrm{~T}_{2}-\mathrm{T}_{1}} \times 100$ (After Brown, 1957)

Where,

$\mathrm{W}_{1}=$ Initial live body weight $(\mathrm{g})$ at time $\mathrm{T}_{1}$ (day).

$\mathrm{W}_{2}=$ Final live body weight $(\mathrm{g})$ at time $\mathrm{T}_{2}$ (day).

$\mathrm{T}_{2}-\mathrm{T}_{1}=$ Time interval

\section{e. Estimation of production of fish and prawn} of fish. 


\section{f. Estimation of survival rate (\%)}

The survival rates of fish and prawn for each treatment were estimated on the basis of number of fish harvested at the end of the experiment. The survival rate was calculated as

$$
\text { Survival rate }(\%)=\frac{\text { No. atcual of fish survived }}{\text { No. initial of fish stocked }} \times 100
$$

\section{g. Feed conversion ratio (FCR)}

$\mathrm{FCR}=$ Total feed consumed/Total live weight gain

\section{Cost benefit analysis}

Cost-benefit ratio was calculated by the following formula:

Total cost $(\mathrm{Tk})=$. Fertilizer + Lime $($ Tk. $)+$ Feed $(T k)+$. Fry $(T k$. + Miscellaneous (Tk.)

Miscellaneous (Tk.) $=$ Labor + Maintenance cost

Total yield $(\mathrm{kg} / \mathrm{ha})=$ Gross production

Total income $(T k)=$. Commodity selling price per unit $\times$ Total yield

Total net income $(\mathrm{Tk})=$. Total income $(\mathrm{Tk})-$. Total cost $(\mathrm{Tk}$.

Rate of return $(\%)=($ Total income $/$ Total cost $) \times 100$

Benefit cost ratio $=$ Total income $/$ Total cost

\section{Statistical analysis}

A one-way ANOVA (analysis of variance) was applied for statistical analysis of the data. Computer handling for data analysis was done by statistical package state graphics version. Significance was assigned at $0.05 \%$ level.

\section{Results}

\section{Water quality parameters}

Temperature: The water temperature varied between 24.0 and $31.0^{\circ} \mathrm{C}$ in the ponds of $\mathrm{T}_{1}$. The highest average temperature $\left(31.0^{\circ} \mathbf{C}\right)$ in $\mathrm{T}_{1}$ was recorded on May 29, 2006. In $\mathrm{T}_{2}$ ponds, the water temperature varied between 24.3 and $31.7^{\circ} \mathbf{C}$. The average highest temperature $\left(31.7^{\circ} \mathbf{C}\right)$ in $\mathrm{T}_{2}$ was recorded on April 29, 2006, while the lowest $\left(24.3^{\circ} \mathbf{C}\right)$ was recorded on April 9, 2006 (Figure 2). The average highest water temperature of $\mathrm{T}_{1}, \mathrm{~T}_{2}$ and $\mathrm{T}_{3}$ were found to be $31.0,31.5$, and $31.4^{\circ} \mathbf{C}$, respectively. The water temperature was found to fluctuate in all the treatments during the study (Figure 2).

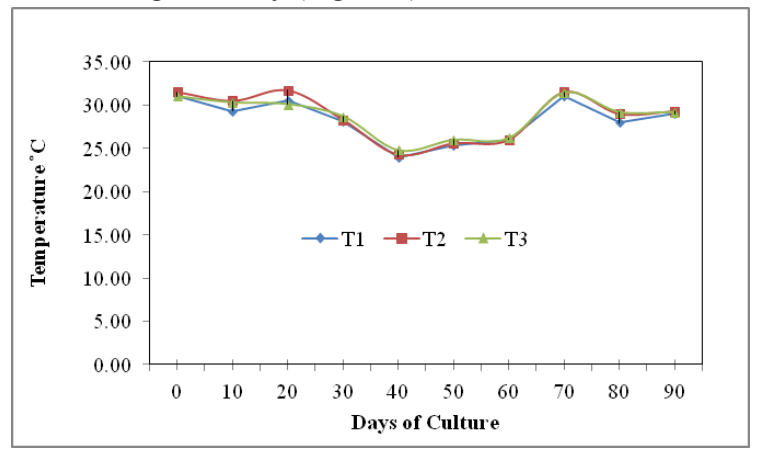

Figure 2 Temperature fluctuations in different treatments during the study period.

\section{$\mathrm{pH}$}

The $\mathrm{pH}$ values of water in all the experimental ponds under different treatment were varied between 7.1 and 8.3. In treatment $T_{1}$, the average highest value of $\mathrm{pH}$ (8.3) was recorded on May 9, 2006, while the lowest (7.1) was recorded on April 9, 2006 (Figure 3). In case of $\mathrm{T}_{2}$ ponds, the $\mathrm{pH}$ of water varied from 6.8 to 8.4 , within which the highest value (8.4) was recorded on June 28, 2006, while the lowest (6.8) was found on March 30, 2006. The $\mathrm{pH}$ values of $\mathrm{T}_{3}$ were found to be fluctuated sharply. The highest value (8.4) was recorded on 30 March 2006, while the lowest value (6.2) was found on June 18, 2006 (Figure 3).

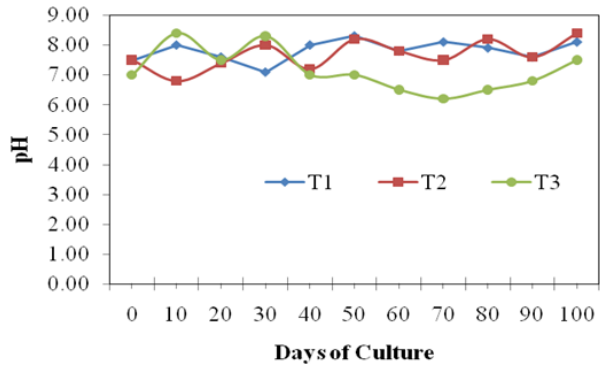

Figure $3 \mathrm{pH}$ values of water in the ponds under three treatments during the study period.

\section{Dissolved oxygen (DO)}

The dissolved oxygen level was observed to be varied unevenly between 4.5 and $6.4 \mathrm{ppm}$ in $\mathrm{T}_{1}, 4.0$ and $5.5 \mathrm{ppm}$ in $\mathrm{T}_{2}$, and 3.2 and 4.5 $\mathrm{ppm}$ in $\mathrm{T}_{3}$ during the entire study period. Therefore, $\mathrm{DO}$ levels were obtained to be within the suitable range only in $T_{1}$ and $T_{2}$ in the present study. However, dissolved oxygen level was found to be fluctuated among all the three treatments (Figure 4).

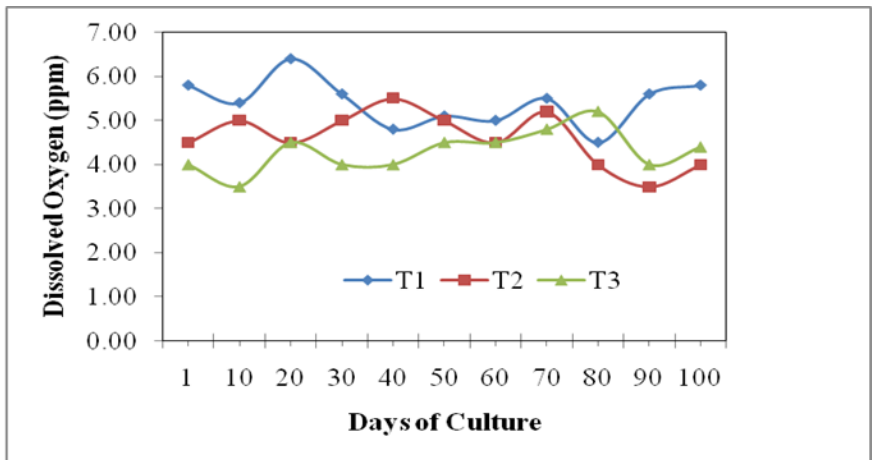

Figure 4 Dissolved oxygen (DO) level as recorded from ponds belonging to the different treatments during the study period.

\section{Transparency}

The water transparency values of the experimental ponds in all the treatments were varied from 28.5 to $44.0 \mathrm{~cm}$. In case of $T_{1}$, the highest transparency value $(34.5 \mathrm{~cm})$ was recorded on March 25, 2006, while the lowest value $(29.4 \mathrm{~cm})$ on June 18,2006 . In $\mathrm{T}_{2}$, the highest value $(32.3 \mathrm{~cm})$ was recorded on March 30 and April 9, 2006, while the lowest $(29.0 \mathrm{~cm})$ on June 18,2006 . The transparency value $(31.2 \mathrm{~cm})$ was recorded on March 25, 2006, while the lowest value $(29.5 \mathrm{~cm})$ on June 18, 2006 (Figure 5). 


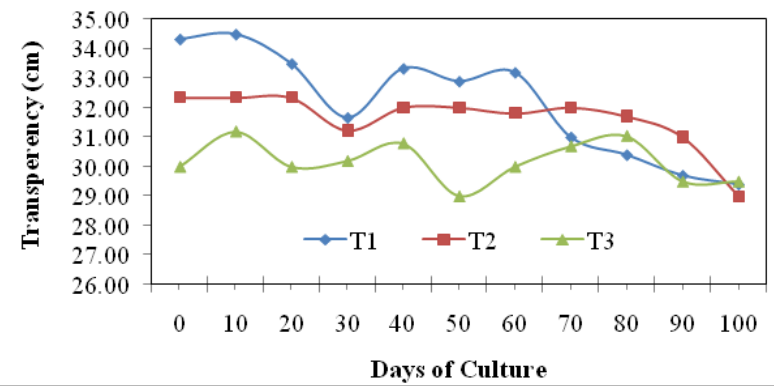

Figure $\mathbf{5}$ Variations of water transparency in the experimental ponds under different treatments during the study period.

\section{Growth and production performances of prawn and fish}

\section{Survival rate}

The average survival of $M$. rosenbergii was estimated to be $85.0 \%$ in $\mathrm{T}_{1}, 71.0 \%$ in $\mathrm{T}_{2}$ and $69.0 \%$ in $\mathrm{T}_{3}$, while the survival of $C$. catla in $\mathrm{T}_{1}, \mathrm{~T}_{2}$ and $\mathrm{T}_{3}$ was found to be $100.0 \%, 91.6 \%$ and $83.3 \%$, respectively (Table 1) (Figure 6).

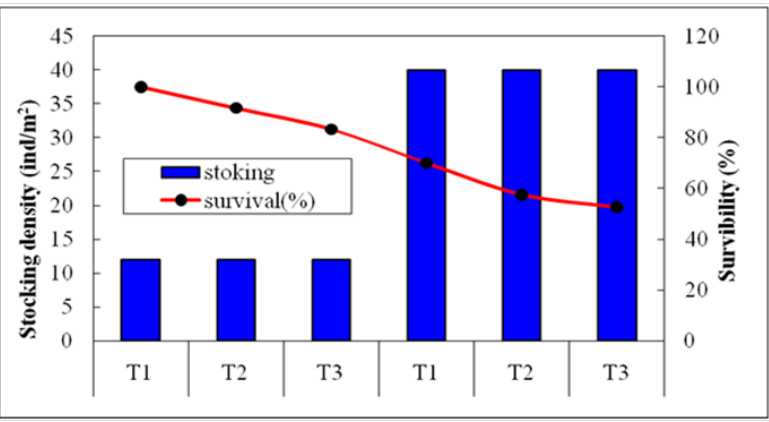

Figure 6 Stocking and Survival rate of catla (Catla catla) and golda (Macrobrachium rosenbergii) in the experimental ponds under different treatments.

\section{Cumulative growth of Catla catla}

After 90 days of culture, the average body weight of catla in the three treatments $\mathrm{T}_{1}, \mathrm{~T}_{2}$ and $\mathrm{T}_{3}$ were found to increase from $50 \mathrm{~g}$ to $292.0,206.0$ and $282.7 \mathrm{~g}$, respectively. The growth performance was found to be better in $\mathrm{T}_{3}$ than that in $\mathrm{T}_{2}$, which might be due to the lower survival rate in $\mathrm{T}_{3}$. The cumulative growth trends of catla in the ponds at the three treatments are shown in Figure 7.

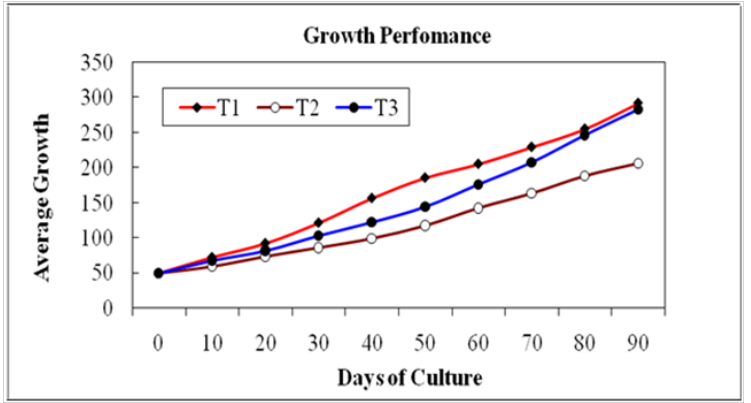

Figure 7 Cumulative growth (g) performance of Catla catla obtained from different treatments.

\section{Specific growth rate (SGR) of Catla catla}

The daily growth rate or specific growth rate (SGR \%/day) of $C$. catla by weight in all the treatments is presented in Figure 8. The SGR was $5.68 \%$ /day in treatment $\mathrm{T}_{1}, 4.28 \%$ /day in $\mathrm{T}_{2}$, while $5.33 \%$ /day in $\mathrm{T}_{3}$, respectively (Figure 8 ).

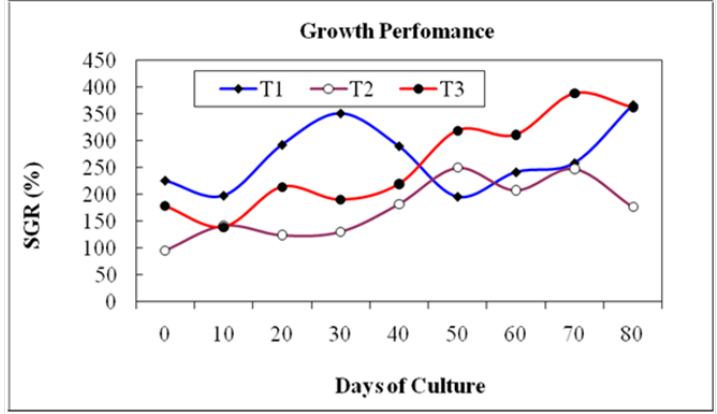

Figure 8 Specific growth rate (SGR \%day) of Catla catla obtained from different treatments.

The analysis of variance proved that the variation in the specific growth rate of catla obtained from different treatments were not significantly different $(\mathrm{p}<0.05)$ (Table 3 ).

Table 2 Stocking and Survival rate (\%) of catla and golda

\begin{tabular}{cllll}
\hline & Treatment & $\begin{array}{l}\text { No. stocked/ } \\
\mathbf{m}^{2}\end{array}$ & $\begin{array}{l}\text { No. } \\
\text { harvested }\end{array}$ & $\begin{array}{l}\text { Survival } \\
\text { (\%) }\end{array}$ \\
\hline \multirow{3}{*}{ Catla } & $\mathrm{T}_{1}$ & 12 & 12 & 100.0 \\
& $\mathrm{~T}_{2}$ & 12 & 11 & 91.6 \\
& $\mathrm{~T}_{3}$ & 12 & 10 & 83.3 \\
& $\mathrm{~T}_{1}$ & 40 & 34 & 85.0 \\
\multirow{3}{*}{ Golda } & $\mathrm{T}_{2}$ & 40 & 29 & 71.0 \\
& $\mathrm{~T}_{3}$ & 40 & 28 & 69.0 \\
\hline
\end{tabular}

Table 3 Analysis of variance (ANOVA) for the specific growth rate (SGR $\%$ day) of Catla catla

\begin{tabular}{lllllll} 
ANOVA & & & & & & \\
\hline $\begin{array}{l}\text { Source of } \\
\text { variation }\end{array}$ & SS & df & MS & F & P-value & F crit \\
\hline $\begin{array}{l}\text { Between } \\
\text { groups }\end{array}$ & 39930.65 & 2 & 19965.32 & 3.853956 & 0.035361 & 3.402826 \\
$\begin{array}{l}\text { Within } \\
\text { groups }\end{array}$ & 124331.4 & 24 & 5180.475 & & & \\
Total & 164262 & 26 & & & & \\
\hline
\end{tabular}

\section{Cumulative growth of Macrobrachium rosenbergii}

The cumulative growth of $M$. rosenbergii by weight obtained from the three treatments is presented in Figure 9. A gradual increasing trend was seen in all the treatments throughout the culture period. The initial average body weight of shrimps in $\mathrm{T}_{1}, \mathrm{~T}_{2}$ and $\mathrm{T}_{3}$ was 5.8, 6.4 and $6.3 \mathrm{~g}$, respectively, which became $94.2,73.8$ and $63.0 \mathrm{~g}$ in $\mathrm{T}_{1}, \mathrm{~T}_{2}$ and $T_{3}$, respectively. $T_{1}$ showed a comparatively higher growth pattern than the other two treatments. 


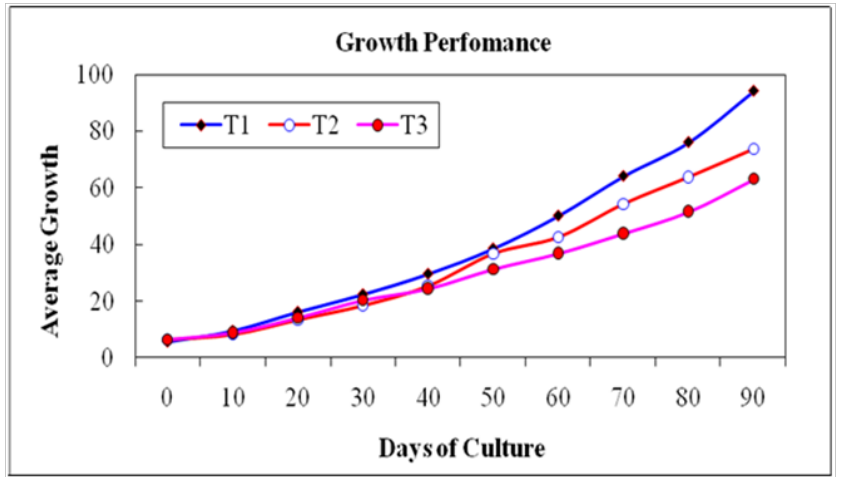

Figure 9 Cumulative growth of Macrobrachium rosenbergii obtained from different treatments.

\section{Specific growth rate (SGR) of Macrobrachium rosenbergii}

The daily growth rate or specific growth rate (SGR) of $M$. rosenbergii by weight in all the treatments is presented in Figure 10. The highest growth rate of $5.2 \%$ /day was observed in $\mathrm{T}_{1}$, followed by $4.7 \%$ /day in $\mathrm{T}_{3}$ and $4.6 \%$ /day in $\mathrm{T}_{2}$ in that order. Comparatively high growth was obtained in $\mathrm{T}_{1}$ than those in other two treatments.

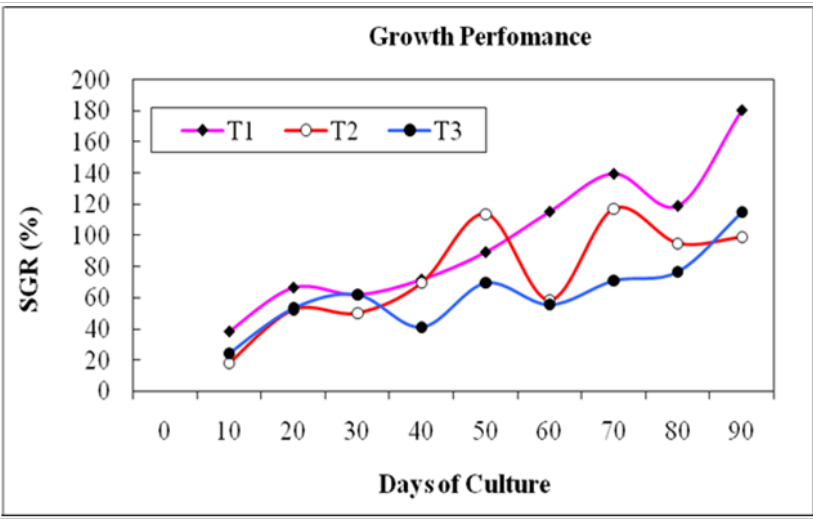

Figure 10 Specific growth rate of Macrobrachium rosenbergii obtained from different treatments.

The analysis of variance (ANOVA) indicated that the variation in specific growth rates of prawn as obtained from different treatments were varied significantly $(\mathrm{p}>0.05)$ (Table 4$)$.

Table 4 Analysis of variance (ANOVA) for the specific growth rate (SGR \%/ day) of Macrobrachium rosenbergii

\begin{tabular}{lllllll}
$\begin{array}{l}\text { Source of } \\
\text { variation }\end{array}$ & SS & df & MS & F & P-value & $\begin{array}{l}\text { F } \\
\text { crit }\end{array}$ \\
\hline $\begin{array}{l}\text { Between } \\
\text { groups }\end{array}$ & 65.70 & 2 & 32.85 & 0.33345 & 0.72 & 3.68 \\
Within groups & 1477.74 & 15 & 98.52 & & & \\
Total & 1543.44 & 17 & & & & \\
\hline
\end{tabular}

\section{Average daily growth of Catla catla}

The average daily growth of C. catla was observed to be 3.24, 2.88 and $3.14 \mathrm{~g}$ in $\mathrm{T}_{1}, \mathrm{~T}_{2}$ and $\mathrm{T}_{3}$, respectively. The highest average daily growth in $\mathrm{T}_{1}$ was $3.66 \mathrm{~g}$ during the 90 days of culture while the lowest value was $1.96 \mathrm{~g}$ during the 60 days of culture. In $\mathrm{T}_{2}$, the highest average daily growth was $2.5 \mathrm{~g}$ during the 60 days of culture and the lowest was $0.96 \mathrm{~g}$ during the first 10 days of culture. In $\mathrm{T}_{3}$, the highest daily growth rate was $3.19 \mathrm{~g}$ during the 60 days of culture and the lowest $1.39 \mathrm{~g}$ was during the 20 days of culture. The average daily growth of the three treatments is shown Figure 11.

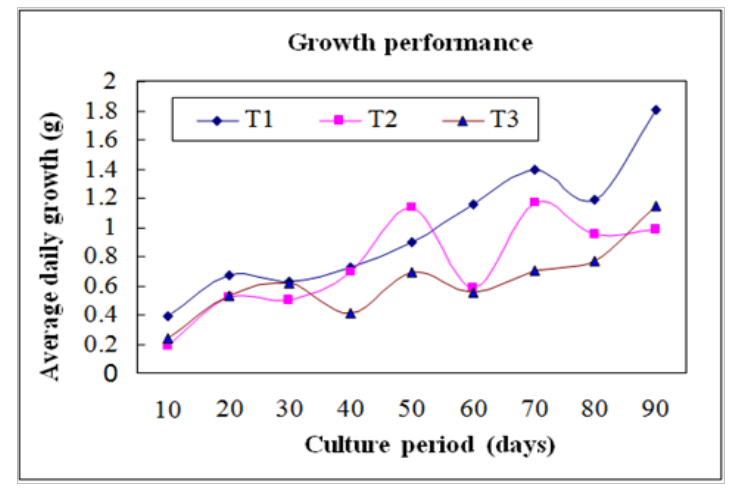

Figure II Average daily growth of Catla catla as obtained from the three treatments.

\section{Average daily growth of Macrobrachium rosenbergii}

The average daily growth of $M$. rosenbergii was observed to be $1.05 \mathrm{~g}, 0.82 \mathrm{~g}$ and $0.70 \mathrm{~g}$ in $\mathrm{T}_{1}, \mathrm{~T}_{2}$ and $\mathrm{T}_{3}$, respectively. The highest average daily growth for $\mathrm{T}_{1}$ was found to be $1.82 \mathrm{~g}$ during the 90 days of culture and the lowest value was $0.39 \mathrm{~g}$ during the 10 days of culture. In $\mathrm{T}_{2}$, the highest average daily growth was found to be 1.17 $\mathrm{g}$ during the 70 days of culture and the lowest was $0.18 \mathrm{~g}$ during the first 10 days of culture. In $T_{3}$ the highest daily growth rate was 1.44 $\mathrm{g}$ during the 90 days of culture and the lowest $0.24 \mathrm{~g}$ was during the 10 days of culture. The average daily growth of the three treatments is shown in Figure 12.

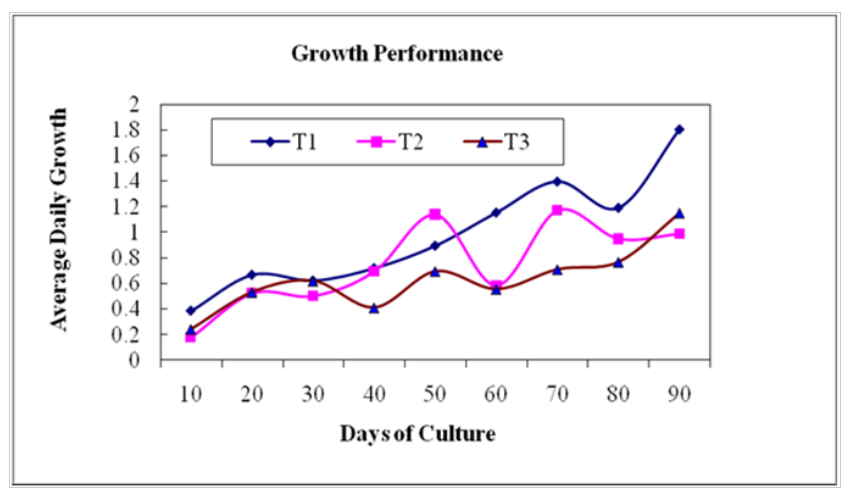

Figure 12 Average daily growth (ADG) of Macrobrachium rosenbergii as obtained from the different treatments.

\section{Production of fish and prawn}

The production of $M$. rosenbergii in all the treatments is presented in Figure 13. Total production $(\mathrm{kg} / \mathrm{ha})$ of $M$. rosenbergii in $\mathrm{T}_{1}, \mathrm{~T}_{2}$ and $\mathrm{T}_{3}$ was found to be $791.00,517.34$ and 429.48 , respectively while for C. catla that was $865.48,559.70$ and 698.19 in $\mathrm{T}_{1}, \mathrm{~T}_{2}$ and $\mathrm{T}_{3}$, respectively. The gross production $(\mathrm{kg} / \mathrm{ha})$ of $M$. rosenbergii and $C$. catla was found to be the highest $(1,615.48)$ in $\mathrm{T}_{1}$ followed by $\mathrm{T}_{2}$ $(1,077.00)$ and $\mathrm{T}_{3}(1,127.48)$.

Feed conversion ratio: Feed conversion ratio obtained from the treatments is shown in Figure 14. FCR in $\mathrm{T}_{1}, \mathrm{~T}_{2}$ and $\mathrm{T}_{3}$ was 1.98, 1.8 and 1.85 , respectively. 


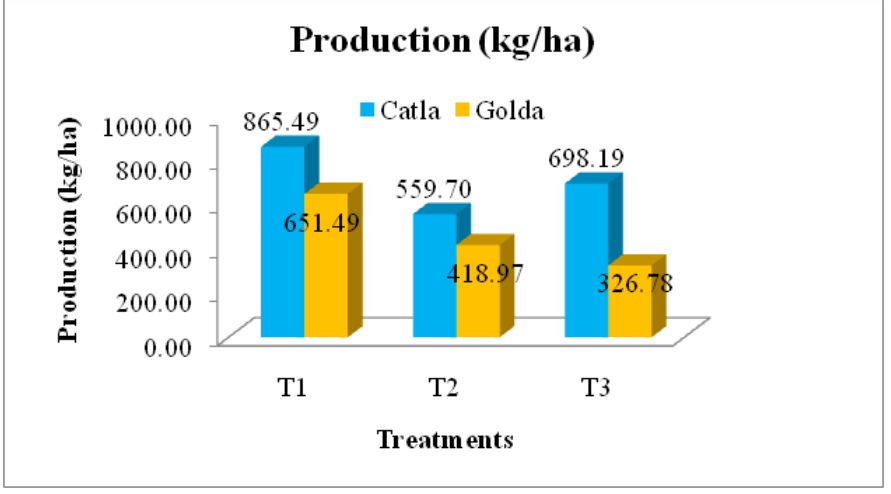

Figure I 3 Production (kg/ha) of Macrobrachium rosenbergii and Catla catla.

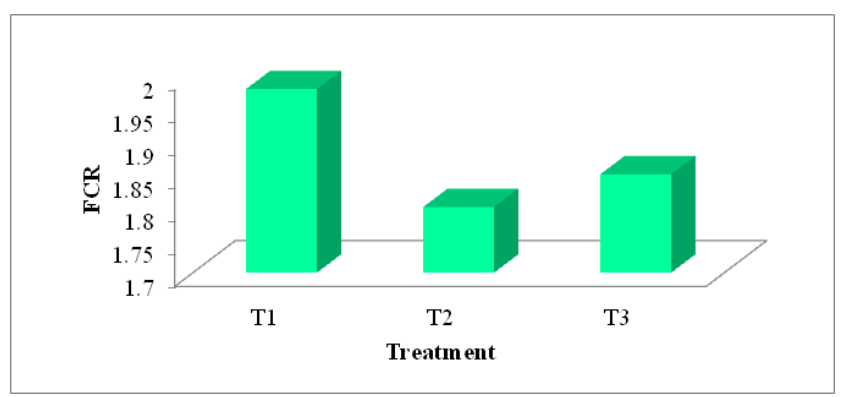

Figure I4 Feed conversion ratio (FCR) obtained from different treatments.

\section{Discussion}

\section{Water quality parameters}

Water temperature: Temperature is one of the most important physicochemical parameters (others are: salinity, $\mathrm{pH}$, water transparency and water depth) that have direct effect on the growth of prawn. ${ }^{9}$ Growth of shrimp was found to be directly related with the water temperature in all the treatment in the present study. Chiu ${ }^{10}$ reported that the optimum temperature for $M$. rosenbergii culture lies between $25^{\circ} \mathrm{C}$ and $32^{\circ} \mathrm{C}$. Apud ${ }^{11}$ mentioned a range of water temperature from $25^{\circ} \mathrm{C}$ to $30^{\circ} \mathrm{C}$ would be favorable for $M$. rosenbergii farming. The recommended range of temperature for prawn is about $25^{\circ} \mathrm{C}$ to $30^{\circ} \mathrm{C} .{ }^{12}$ The results obtained from the present study are comparable with that of Rahman et al. ${ }^{13}$ The present findings also agree well with those of Paul. $^{14}$

\section{$\mathrm{pH}$}

The best range of water $\mathrm{pH}$ for shrimp culture lies between 7 and $9 .{ }^{15}$ The $\mathrm{pH}$ values as recorded from the experimental ponds under different treatments in the present study were within this range. $\mathrm{Chiu}^{10}$ noted that optimum range of $\mathrm{pH}$ was $6.8-8.7$ for prawn culture. Kohinoor ${ }^{16}$ recorded $\mathrm{pH}$ values of 6.5 to 8.0 , Raihan ${ }^{17}$ found $\mathrm{pH}$ values ranged from 6.80 to 9.24 and $\mathrm{Uddin}^{18}$ recorded $\mathrm{pH}$ values of 6.14 to 8.88 in the polyculture ponds at BAU campus. Low pH reduces ammonia toxicity ${ }^{19-21}$ and mobilizes metals, including iron and aluminum, which can reduce yields in aquaculture ponds. ${ }^{22}$ Low $\mathrm{pH}$ can also reduce natural pond productivity presumably by reducing the availability of nutrients including phosphorous and carbon sources (e.g. bio-carbonates and alkalinity) for photosynthesis. ${ }^{23}$

\section{Dissolved oxygen}

The dissolved oxygen contents in the experimental ponds throughout the study were ranged from 3.2 to $6.4 \mathrm{ppm}$. The result obtained in the present study was more or less agree with those of Wahab et al., ${ }^{24}$ who recorded dissolved oxygen ranging from 3.4 to 7.79 ppm, Kohinoor ${ }^{16}$ reported dissolved oxygen from 2.0 to $7.4 \mathrm{ppm}$ and $\mathrm{Uddin}^{18}$ from 2.2 to $8.8 \mathrm{ppm}$, and they also reported that, this range of dissolved oxygen is good for fish production, and water having dissolved oxygen below $5 \mathrm{ppm}$ is unproductive. It may be concluded that dissolved oxygen content in the ponds under present study was more or less suitable for fish production..$^{25}$

\section{Water transparency}

The recommended level of water transparency for prawn farming is between 35 and $60 \mathrm{~cm} .{ }^{26,27}$ The water transparency was higher than the recommended values during the culture period in all the ponds during this study. The lower daily growth rate of $M$. rosenbergii in all the treatments may be due to the high water transparency as well as the declination of natural food organisms. Boyd ${ }^{23}$ recommended a transparency range of $15-40 \mathrm{~cm}$ as appropriate for pond fish culture. Wahab et al. ${ }^{24}$ reported that the transparency of productive water bodies should be $40 \mathrm{~cm}$ or less. However, the transparency in the present experimental ponds was slightly higher than the recommended level for the carp-golda polyculture.

\section{Growth and production performances of catla and prawn}

Stocking and survival of fish and prawn: In case of prawn $(M$. rosenbergii), the survival rates $(85.0 \%, 71.0 \%$ and $69.0 \%)$ obtained at a stocking density of $40 / \mathrm{dec}$ in the present study are more or less similar to those of D'Abramo et al. ${ }^{28}$ who noted that the survival rate of prawn was ranged from $54.3 \%$ to $89.0 \%$ in earthen ponds. Siddiqui and Al-Hinty ${ }^{29}$ obtained the survival rate of fresh water prawn $(M$. rosenbergii), which was varied from $71.0 \%$ to $93.0 \%$. Islam et al. ${ }^{30}$ reported that a stocking density of $90 \mathrm{PL} / \mathrm{dec}$ was optimum in India. Ang $^{31}$ investigated the potential of $M$. rosenbergii culture in Malaysia and obtained the total production of $977 \mathrm{~kg} / \mathrm{ha} / 158$ days cycle with a survival rate of $32.4 \%$ at the stocking density of $10 \mathrm{PL} / \mathrm{m}^{2}$. Daniels et al. ${ }^{32}$ reported the higher survival rates of $73.7 \%$ to $81.9 \%$ in $M$. rosenbergii when fed with formulated diet in earthen ponds. The survival of C. catla was high and ranged from $83.3 \%$ to $100.0 \%$ in all the treatments, which is more or less similar to that of Miah et al. ${ }^{33}$ The use of inorganic and organic fertilizer, and supplemental feed might have resulted in good survival for the fish in all the treatments in the present study. Similar results have also been reported by Lakshmanan et al. ${ }^{34}$ However, the highest survival $(100.0 \%)$ found in $\mathrm{T}_{1}$ was higher than that obtained by Ali et al. ${ }^{35-37}$

\section{Growth of fish and prawn}

In the present study, the non-significant difference in growth between $T_{1}$ and $T_{2}$ was probably due to the fact that prawn could not compensate their growth due to feed deprivation. While the existence of significant difference among the three treatments was due to different feeding methods. Chand et al. ${ }^{38}$ reported that the daily weight gains of catla, rohu and prawn were $3.29,2.79$ and $0.21 \mathrm{~g} /$ day, respectively. The results of the present study were higher than the findings of Sadek and El-Gayer, ${ }^{39}$ who found that the daily weight gain of $M$. rosenbergii was ranged between 0.318 and $0.319 \mathrm{~g}$. The maximum SGR was found in $\mathrm{T}_{1}(5.2)$ and minimum in $\mathrm{T}_{3}(3.2)$ in the present study, which was in some extent higher than the findings 
of Sharma and Reddy, ${ }^{40}$ might be due to stocking of juveniles and everyday feeding. Islam et al. ${ }^{41}$ reported that this variation in SGR might be due to the culture environment, feeding trial, stocking densities and season of the study.

\section{Feed conversion ratio}

The FCR values obtained from different treatments in the present study for catla and prawn were more or less similar to the values reported by Siddique et al. ${ }^{42}$ The FCR of $\mathrm{T}_{1}(1.98)$ is highly satisfactory when compared with the findings of $\mathrm{Liao}^{43}$ and Biswas. ${ }^{44}$

\section{Production of fish and prawn}

The highest production of prawn and catla in $T_{1}$ and the lowest production in $\mathrm{T}_{3}$ were probably due to the fact that the growth rate of prawn has been inhibited because of the minimum utilization of supplementary feed. Ali et al. ${ }^{35}$ conducted a study to observe the effect of different periods of starvation and subsequent re-feeding on growth, survival and daily food demand etc. of prawn $(M$. rosenbergii) and catla (C. catla) and reported that prawn could be cultured at alternate day feeding protocol and thus feed cost should be substantially reduced. $\mathrm{Mia}^{45}$ obtained the highest production of prawn and fish as 122 and 4,200 kg/ha in the first year, and 96 and $3,945 \mathrm{~kg} / \mathrm{ha}$, respectively in the second year. He concluded that the low production might be due to low temperature. Huq et al. ${ }^{46}$ found the survival of prawn in monoculture and polyculture as $65 \%$ and $75 \%$, respectively while the survival of both rohu and catla was $90 \%$. They obtained the total production of prawn in monoculture and polyculture system as 606.8 and $605.2 \mathrm{~kg} / \mathrm{ha}$, while the production of rohu and catla in polyculture were 619.1 and $584.2 \mathrm{~kg} / \mathrm{ha}$, respectively. Jose et al. ${ }^{47}$ reported a gross production of $106-25 \mathrm{~kg} / \mathrm{ha}$ of prawn from 160 days of culture in India, where M. rosenbergii was stocked at 10,000/ ha with catla, rohu and mrigal $(2: 2: 1)$ at a density of 1,000/ha. On the other hand, Islam et al. ${ }^{30}$ reported a production of $172 \mathrm{~kg} / \mathrm{ha} / 12$ months, where $M$. rosenbergii was stoked at 15,000 /ha with silver carp, catla rohu and mrigal $(1.75: 0.75: 1.50: 1.0)$ at a stocking density of $5,000 / \mathrm{ha}$ in each pond. Hoq et al ${ }^{48}$ reported a production of $428 \mathrm{~kg} /$ ha of prawn in 10 months, where prawn and fish density was $18,000 /$ ha. Haque et al. ${ }^{49}$ used prawn stocking densities at 15, 20, 25, 30, 35 and 40 /decimal in each treatment, and obtained the productions of 120.9 to $216.1 \mathrm{~kg} / \mathrm{ha} / 4$ months, while that of carps was $2,248.8$ to $2,359.2 \mathrm{~kg} / \mathrm{ha} / 4$ months. The production range of prawn in the present study was higher than the findings of Haque et al. ${ }^{49}$ even with a low stocking density. This might be due to the lower stocking density of carp. In the present study, it was found that the growth and production of the prawn and carp were remarkably affected by supplemental feeding. The findings also revealed that the highest production in $\mathrm{T}_{1}$ was due to regular twice daily feeding and the lowest production was found in $\mathrm{T}_{3}$, where supplemental feed was applied once in every two days.

\section{Conclusion}

The results of the study revealed that prawn fed to satiation twice a day $\left(\mathrm{T}_{1}\right)$ had better growth performances and survival than those of the other two treatments. In $\mathrm{T}_{2}$ (fed every alternate day) and $\mathrm{T}_{3}$ (fed every two days of interval), prawn could not compensate their growth and the average weight at final harvest was much lower than that of $T_{1}$. Though, better FCR of prawn was seen in $T_{2}$ followed by $T_{1}$ and $\mathrm{T}_{3}$ but the mean weight at harvest was the highest in $\mathrm{T}_{1}$. Finally, the overall production of prawn was found to be the highest in $T_{1}(791.0$ $\mathrm{kg} / \mathrm{ha})$ and the lowest in $\mathrm{T}_{3}(429.5 \mathrm{~kg} / \mathrm{ha})$.

The net profit of prawn was much higher in $T_{1}$. So, in terms of production cost and gross returns, $T_{1}$ is more profitable than the other two treatments. In this way, farmers can get more profit and save the feed cost by maintaining proper feeding management. The study has provided evidence that prawn could be cultured in feeding regime with feeding at everyday with satisfactory growth and final production. Feed cost is perhaps the largest operational cost in all kind of aquaculture. So, it has become necessary to produce the maximum quantity of fish with minimum amount of feed to reduce the fish production cost to a greater extent. Prawn needs commercial pelleted feed to grow, while catla does not need any extra feed if they are released at a low density. However, to save feed cost, commercial diet should be used in a more efficient way. Moreover, the gross production of fish and prawn can be enhanced much with the minimum feed cost through adoption of proper culture practices, administration of good quality feed and maintenance of proper species combinations. However, it needs further studies with many more variables to develop the sustainable prawn-carp polyculture technology.

\section{Acknowledgements}

The authors would like to extend grateful thanks and appreciations to the Ministry of Education, and Ministry of Fisheries and Livestock, Bangladesh for funding this study and the Department of Aquaculture for assisting their laboratory facilities.

\section{Conflicts of interest}

The author declares there is no conflict of interest.

\section{References}

1. DoF. Fish fortnight compendium 2005. Department of Fisheries, Bangladesh; 2005:63-68.

2. FAO/UNDP. Twenty year fishery development plan in Bangladesh. USA: J.C. Marr Associates; 1985. 321 p.

3. Cruz EM, Landencia IL. Polyculture of milkfish (chanos chanos Forskal), in freshwater ponds with supplemental feeding. Aquaculture. 1980;20(3):231-237.

4. Shephered J, Bromage N. Intensive fish farming. Oxford, UK: Blackwell scientific publications; $1988.404 \mathrm{p}$.

5. Opuszynski K. Polyculture in carp ponds. In: Billard R, Marcel J, editors. Aquaculture of Cyprinids. Paris: INRA; 1986:269-281.

6. Ahmed N. Socio-economic aspects of fresh water prawn culture development in Bangladesh. Ph.D. Thesis, Institute of Aquaculture, UK: University of Stirling; 2001. 320 p.

7. DoF. Fish fortnight compendium. Department of Fisheries, Ramna, Dhaka, Bangladesh: Government of the People Republic of Bangladesh; 2002:44-45.

8. Haque ME. Statistics of fisheries resource in Bangladesh. In: Mazid MA, editor. Technology and Management for Fisheries Development. Mymensingh: Fisheries Research Institute; 1996:127-131.

9. Lester LJ, Pante MJR. Penned temperature and salinity responses. In: Fast AW, Lester LJ, editors. Marine Shrimp Culture: Principles and Practices. Amsterdam: Elsevier; 1992:515-534.

10. Chiu YN. Site selection for intensive prawn farms. In: Chiu YN, Santos LM, Juliano RO, editors, Technical consideration for the management and operation of intensive prawn farms. Iloilo City, Philippines: 
Aquaculture society; 1988:25-28.

11. Apud FD. Recent developments in prawn pond culture. Aquaculture extension pamphlet no. 1 May, 1989. Aquaculture Department, Tigbauan, IIoilo, Philippines: SEAFDC; 1989. 24 p.

12. Annon. Shrimp culture: pond design, operation and management. Selected pub. No. 2 for commemorating World food day. Bangkok, Thailand: Network of Aquaculture Centre in Asia; 1986:15-48

13. Rahman MS, Chowdhury MY, Haque AKMA, et al. Limnological studies of four ponds. Bangladesh J Fish. 1982;25(1-2):25-35.

14. Paul S. Comparison between carp polyculture system with silver carp (Hypophthalmichthys molitrix) and small indigenous fish species (SIS) mola (Amblypharingodon mola). M.S. Dissertation, Department of Fisheries Management, Mymensingh: Bangladesh Agricultural University; 1998. 85 p.

15. Boyd CE, Fast AW. Pond monitoring and management. In: Fast AW, Lester LJ, editors. Marine Shrimp Culture: Principles and Practices. Amstardam: Elsevier; 1992:497-508.

16. Kohinoor AHM. Development of culture technology of three small indigenous fish mola (Amblypharyngodon mola), punti (Puntius sophore) and chela (Chela cachius) with notes on some aspects of their biology. Ph.D. thesis, Department of Fisheries Management, Faculty of Fisheries, Mymensingh: Bangladesh Agricultural University; 2000:91102.

17. Raihan A. To assess the effects of adding punti (Puntius sophore) and mola (Amblypharyngodon mola) in carp polyculture. M.S. Dissertation, Department of Fisheries Management, Mymensingh: Bangladesh Agricultural University; 2001. 65 p.

18. Uddin MM. Effects of addition of small fish on pond ecology and production in polyculture. M.S. dissertation, Department of Fisheries Management, Mymensingh: Bangladesh Agricultural University; 2002. $91 \mathrm{p}$.

19. Whitfield M. The hydrolysis of ammonium ions in sea-water; a theoretical study. J Mar Biol Assoc. 1974;54:565-580.

20. Avault JW. Seven years of pond research with the prawn (Macrobrachium rosenbergii) in Louisiana. Magazine. 1986;12(4):51-54.

21. Swingle HS. Relationship of $\mathrm{pH}$ of pond water and their suitability for fish culture, Proc Pacific Sci Congrss. 1961;9(10):72-75.

22. Simpson HJ, Ducklow HW, Deck B, et al. Brackish water aquaculture in pyrite-bearing tropical soils. Aquaculture. 1983;34:333-350.

23. Boyd CE. Water quality management for pond fish culture. New York USA: Elsevier Sci Publ Co; 1982. 318 p.

24. Wahab MA, Ahmed ZF, Islam A, et al. Effect of introduction of common carp, Cyprinus carpio (L.) on the pond ecology and growth of fish inpolyculture. Aquacult Res. 1995;26:619-628.

25. Ferdous MJ. A study on the effect of Feed deprivation in freshwate prawn (Macrobrachium rosenbegii) and Indian major carp, catla (Catla catla), and rohu (Labeo rohita) Polyculture. M.S. Thesis, Department of Fisheries Biology and Genetics, Mymensingh: Bangladesh Agricultural University; 2004

26. Annon. Prawn Raising Manual. The B-MEG shrimp technical service group, the shrimp sales group and the calatrava research group. Feed Business San Miguel Foods Inc; 1992:8-15.

27. Hossain MA, Siddeque MAL, Miaje MAH. Development of low-cos feed for culture of giant freshwater prawn (Macrobrachium rosenbergii, de Man) in ponds. Bangladesh J fish Res. 2000;4:127-134.

28. D'Abramo LR, Heinen JM, Robinette HR, et al. Production of the Fresh water prawn (Macrobrachium rosenbergii) stocked as juveniles at different densities in temperate zone ponds. $J$ World Aquacult Soc. 1989;20(2):81-89.

29. Siddiqui AD, AI-Hinty HM. Feasibility of fresh water prawn, (Macrobrachium rosenbergii) culture in the central region of Saudi Arabia. Effect of destiny on growth, yield and population structure. In: Proc. First International Symposium of Aquaculture Technology and Investment Opportunities. Riyadh, Saudi Arabia: Ministry of Agriculture and water; 1993:304-320.

30. Islam MR, Saha SB, Mollah MFA, Rokeya JA. Polyculture of Macrobrachium rosenbergii (de Man) with carps in ponds. Bangladesh J Fish. 1999;22(1):39-44.

31. Ang KJ. Evaluation of the production potential of Macrobrachium rosenbergii in monoculture in Malaysia. In: Hirano R, Hanyu I, editors. Second Asian Fisheries Forum, Manila, Philippines: Asian Fisheries Society; 1990:103-106.

32. Daniels WH, Abramo LRD, Fonderen MW, et al. Effects of stocking densities and feed on pond production characteristics and revenue. Graded Juveniles. J World Aquacult Soc. 1995;26(1):38-47.

33. Miah MS, Uddin MS, Shah MS. Effect of stocking densities on the growth and production of fishes in mixed polyculture systems. Bangladesh J Fish. 1997;20(1-2):15-138.

34. Lakshmanan MAV, Sukumaran KK, Murty DS, et al. Preliminary observation on intensive fish farming in fresh water ponds by the composite culture of Indian and exotic species. J Inland Fish Soc. 1991;2:1-21.

35. Ali MO, Sarker MK, Lucky NS, et al. Effect of feed deprivation on growth and survival of freshwater prawn (Macrobrachium rosenbergii) and Indian major carp catla, Catla catla in a polyculture system. Progress Agric. 2003;14(1\&2):103-108.

36. Jena JK, Mukhopadhyay RT, Aravandakshan PK. Evaluation of formulated diet for raising carp fingerling in field conditions. Appl Ichthyol. 1998;15:188-192.

37. Hossain MY. Effects of iso-phosphorous organic and inorganic fertilizer on water quality parameters and biological production. M.S. Thesis, Department of Fisheries Management, Mymensingh: Bangladesh Agricultural University; 2000. 74 p.

38. Chand BK, Patra BC, Das SK. Growth and production of freshwater prawn and carp under polyculture system. $J$ Interacademicia. 2002;6(2):210-215.

39. Sadek SS, L-Gayer FMHE. Production of the giant fresh water prawn (Macrobrachium rosenbergii) reared in brackish water ponds (Egypt). International Symposium on Aquaculture Technology and Investment Opportunities. Ministry of Agriculture and water, Riyad, Saudi Arabia. 1993;296-303.

40. Sharma M, Reddy AK. Intensive culture of fresh water prawn (Macrobrachium rosenbergii) in cement tanks. Fish Chimes. 1996;16(9):25-26.

41. Islam MS, Sadek QAM, Mohiuddin M, et al. A brief progress report of farming systems research. On farm Research Division, Milk Vita Road, Dewla, Tangail, Bangladesh: Bangladesh Agricultural Research Institute; $1991.26 \mathrm{p}$

42. Siddique MAL, Hossain MA, Miaje MAH. Polyculture of giant freshwater prawn, Macrobrachium rosenbergii with Indian major carps in ponds with supplemental feed. Bangladesh J Fish. 1999;22(2):67-74.

43. Liao IC. Status and problems of prawn culture in Taiwan. Paper presented at the ROC-Japan Symposium on Mariculture, Taipei, Taiwan; 198:1-7.

44. Biswas NC. An economic Analysis of fish culture under different pond size. Bangladesh J Aquacult. 1996;2:99-110. 
45. Mia MY. Cultivation of prawn in polyculture with some species of Indian and Chinese major carps. Pak J Sci Indust Res. 2004;47(2):107-111.

46. Huq KA, Monir SMI, Rahman MM, et al. Production performance of Macrobrachium rosenbergii (de Man) monoculture vursus polyculture system. Bangladesh J Fish. 2004;2(1):141-149.

47. Jose S, Nair CM, Thampy DM. Culture of Macrobrachium rosenbergi in homestead ponds. In: Silas EG, editors. Fresh water prawns. Thrissur, India: Kerala Agricultural University; 1992:147-152.

48. Hoq ME, Islam MM, Hossain MM. Polyculture of fresh water prawn (Macrobrachium rosenbergii) with Chinese and Indian major carps in farmar's pond. J Aqua Trop.1996;11:135-141.

49. Haque MM, Narejo NR, Salam MA, et al. Determination of optimum stocking density of Macrobrachium rosenbergii in carp polyculture in earthen pond. Pak J Bio Sci. 2003;(16):898-901. 